\title{
NOTES ON THE DISTRIBUTION OF RED ALGAE (RHODOPHYTA) ON THE CORAL REEF OF PARI ISLANDS, SERIBU ISLANDS
}

\author{
by \\ WANDA SURJANA ATMADJA ${ }^{1)}$
}

\begin{abstract}
Many species of red algae are economically important for their carrageenan contents. Since May 1974 to June 1975 an intensive survey on their distributions have been carried out on the fringing reef of Pari Islands, Seribu Islands.

Thirty five species of Rhodophyta have been identified and their species composition and relative importance as compared to Phaeophyta and Chlorophyta have been studied.

Environmental factors, such as bottom type and seasonal influence on their distribution, emphasized in the discussion.

Further studies on inventory and the distribution of these algae will be continued particularly in support of the culture experiments for some of the species.
\end{abstract}

\section{INTRODUCTION}

Some species of red algae are economically important as supplementary food and as raw materials for industries producing carrageenan for cosmetics, pharmacies, etc.

The inventory of algae in some areas is important for further studies on their taxonomy, morphology, and distribution. The data obtained is also necessary to support marine culture experiments. Marine culture helps improving natural stock which is being depleted by environmental factors.

Some investigators have been working on the same subject with different methods such as collecting, transecting, and standing crop assessing. TAYLOR (1937) and DAWSON (1955) made their studies in USA; ZANEVELD (1955) and SURJodinoto \& PARDANINGSiH (1964) in Indonesia, TSUDA (1972) in the Caroline Island, VARMA \& RAO (1962) in India, and DOTY (1970) in the Philippines.

The economically important algae in Pamban area, India, were confined to shallow regions, generally tp depths less than $2-3$ meters and .practically none of the weeds are found deeper than 7 meters. They are distributed along the coral beds or on the rocky substratum covered with a thin layer of sand (VARMA \& RAO 1962).

1) National Institute of Oceanology, Indonesian Institute of Sciences, Jakarta, Indonesia 
Thirteen genera of edible and commercial algae were recorded from the coral reef of Pari Island, five of which were red algae (SURJODINOTO \& PARDANINGSIH 1964)

Some species of Rhodophyta are depositors of calcium carbonate i.e. calcareous algae like Liagora sp., Peyjssonelia sp. and other species of Corallinaceae (DAWSON 1966)

SUKARNO (1975) found that algae formed the dominant biota on the reef flats of Ayer Island, growing attached on rubbles or hard substrate and in the algal regions on the outer edges of the reef, where groups of Scleractinian corals were rare.

\section{MATERIALS AND METHODS}

Pari Islands $\left(05^{\circ} 50^{\prime} 40^{\prime \prime}-05^{\circ} 52^{\prime} 50 "\right.$ S Lat., $106^{\circ} 34^{\prime}-106^{\circ} 38^{\prime} \mathrm{E}$ Long.) is a group of reef islands, consisting of five islands (Pari Isl., Tengah Isl., Kongsi Isl., Burung Isl., and Tikus Isl.) and seven lagoons (Besar, Ciaris, Koanji, Labangan pasir, Soabesar, Buntu, and Kurungan). Encircling these islands is a barrier reef with six channels that provide water circulation to the reef flats. The reefs form a "pseudo atoll" of 15,430,824.76 square meters, with tide pools and tidal zones which occupies an area of $11,231,330.77$ square meters, and 3,367,324.35 square meters of lagoons (SURYODINOTO 1967).

The difference between low and high water in this area is about one meter. Most of the reefs (sand flats) are not submerged during low tides except the moat with rubble substrates (Figs. 1, 2, and 3).

The data were obtained by observation, collection (made during December 1973 to May 1975), transect measurements (made during July 1972 to June 1975), and by standing crop determinations (made during August 1974 to January 1975). In the last case, transect lines were stretched at north-south direction, parallel to and at one to two hundred meters distance from one another. Observations were made by counting the number of species and the number of specimens for each species of algae found within one square metre areas along the transect lines. The distance between one area and the other is ten metres. Standing crop determinations were based on the wet weight of each algal species harvested per square meter. The samples were placed in $70 \%$ alcohol as liquid preservations and were also preserved as dry herbaria. 
NOTES ON THE DISTRIBUTION OF RED ALGAE

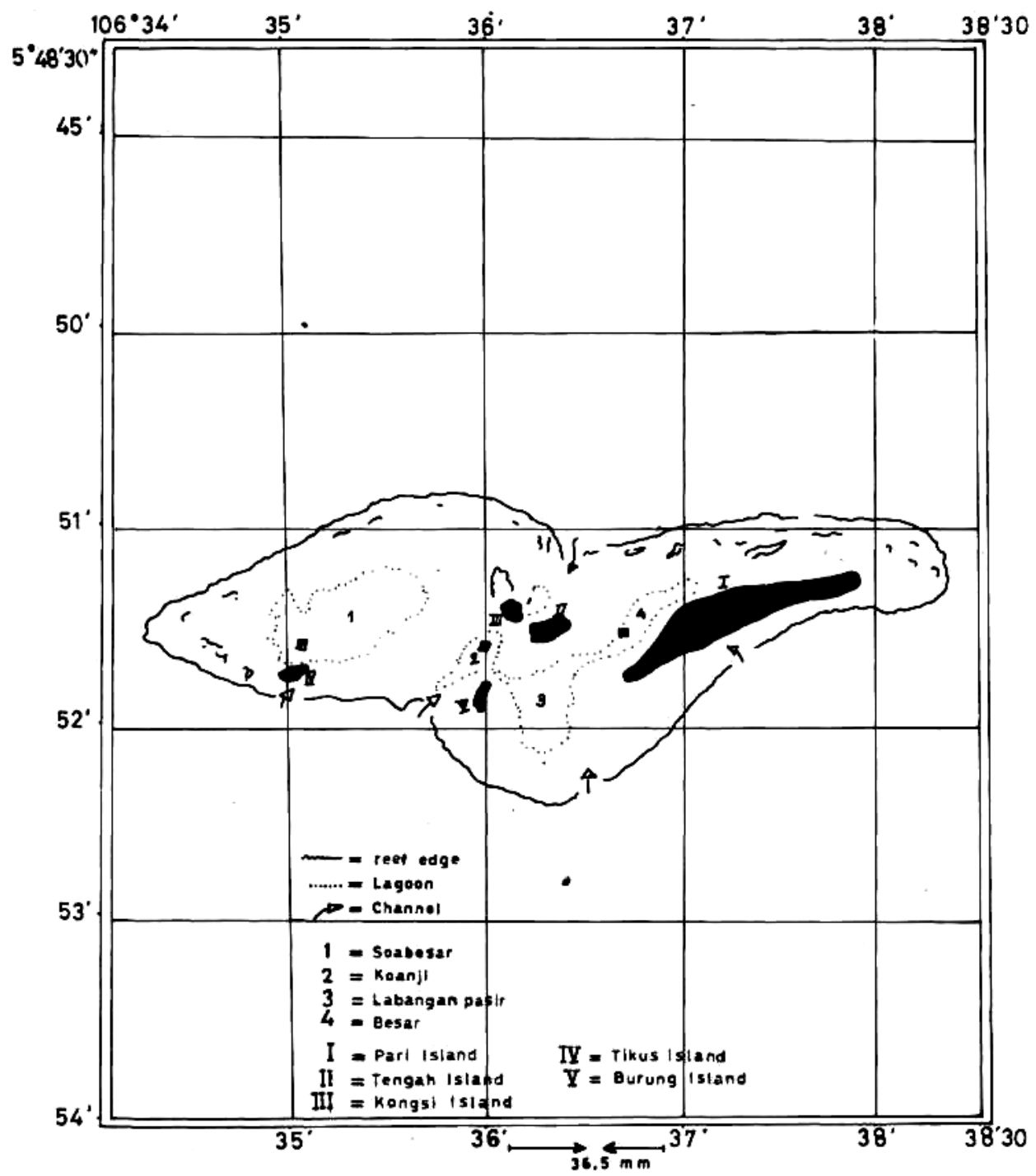

Figure 1. Pari Islands group 
WANDA SURJANA ATMADJA

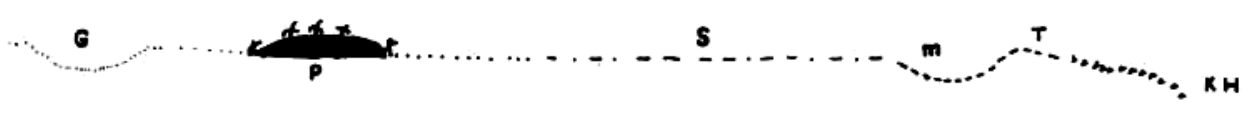

\begin{tabular}{|c|c|c|c|}
\hline 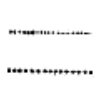 & $\begin{array}{l}\text { Muddy sand } \\
\text { Sand }\end{array}$ & $\begin{array}{l}\mathbf{G} \\
\mathbf{P}\end{array}$ & $\begin{array}{l}\text { Lagoon } \\
\text { Island }\end{array}$ \\
\hline neresurour & $\begin{array}{l}\text { Rock / coral shingle } \\
\text { Living corals }\end{array}$ & $\begin{array}{l}S \\
T\end{array}$ & $\begin{array}{l}\text { Sand flat } \\
\text { Reef edge }\end{array}$ \\
\hline$f$ & Coconut tree & KH & Living corals \\
\hline$\kappa$ & Mangrove & $M$ & Moat \\
\hline
\end{tabular}

Figure 2 : Cross section of typical bottom area in the coral reef of Pari Island. 
NOTES ON THE DISTRIBUTION OF RED ALGAE

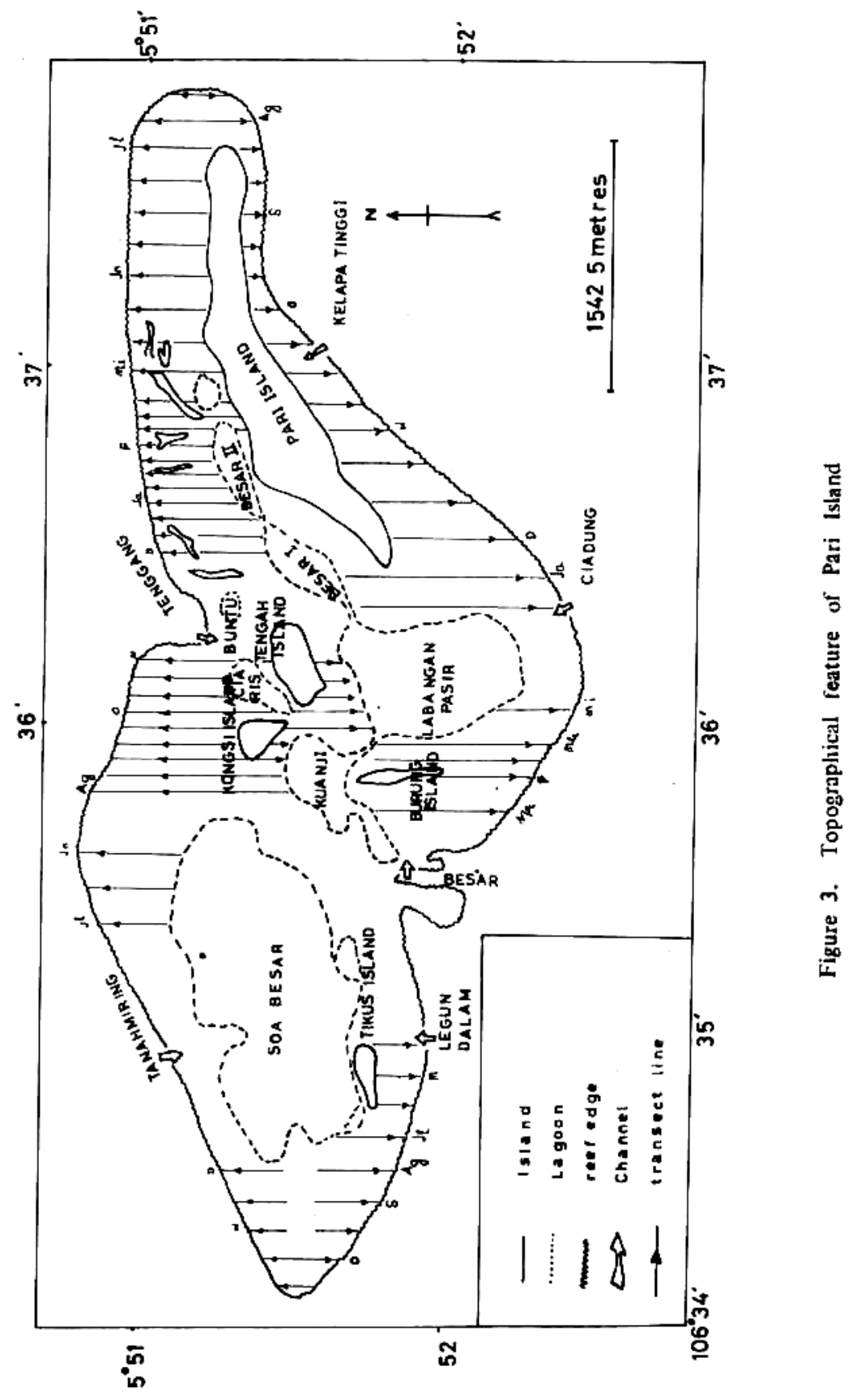


WANDA S URJANA ATMADJA

RESULTS

\section{OBSERVATIONS AND COLLECTION}

Thirty five species of red algae (Rhodophyta) are identified from the collections (Table I).

Table I. List of the red algal species from the coral reef of Pari Island

Ceramiales

Rhodomelaceae

Acanthophora LAMOUROUX

Acanthophora dendroides HARV

A. spicifera (FAHL) BOERG

Chondria C. AGARDH

Chondria dasyphylla (WOODW) C.AG.

Laurencia LAMOUROUX

L. parvipapillata TSENG

L. obtusa (HUDS) LAMX

Polysiphonia GREV.

Polysiphonia flexicaulis (HARV) COLL.

Polysiphonia sp.

Ceramiaceae

Ceramium ROTH

Ceramium deslongchampii CHAUVIN.

Delesseriaceae

Zellere v. MARTIN

Zellere tawalline v. MARTIN

Cryptonemiales

Corallinaceac

Amphiros LAMOUROUX

Amphiroe fragillisima (LINN) LAMX.

Amphiroa foliacea LAMX

Goniolithon FOSLIE

Goniolithon sp.

Jania

Jonia sp.

Lithothamnion PHILIPPI

Lithothamnion sp.

Gelidiales

Gelidiellaceae

Gelidiella

Gelidiella sp.

Grateloupiaceae

Halimenis C. AGARDH
Halimenia sp.

H. durvillaei BORY

Gigartinales

Gracilariaceae

Gracilaria GREVILLE

Gracilaria sp.

G. arcuate ZAN.

G. eucheumioides HARVEY

Corallopsis GREVILLE

Corallopsis salicornia (MART) GREV.

Soliriaceae

Eucheuma J.AG.

Eucheuma spinosum (LINN) J.AG.

E. edule (KUTZ)

Hypneaceae

Hypnea LAMX

Hypnea nidifica J.AG.

H. cenomyce J.AG.

H. chordareae KUTZ

H. cervicornis J.AG.

H. choroides LAMX

H. musciformis KUTZ

H. nidulans SETCH

Nemalionales

Rhyzophylidaceae

Chondrococcus KUTZINGI

Chondrococcus hornemanii (MERT) SCHM.

Helıninthocladiaceae

Galaxaura

Galaxaura spp.

Liagora LAMOUROUX

Liagora ceranoides LAMX

Chaetangiaceae

Scinae BIVONA

Scinae sp. 
Algal growths are generally found on rocky substrates or dead corals which are permanently submerged at the moat of reef.

Laurencia, Hypnea, and Acanthophora are found on sand flats. At the slopes of reef, Galaxaura, Liagora, and Zellera are collected. Halymenia durvillae and Hypnea sp. are found attached on living corals. The genera Amphiroa, Lithothamnion, and Goniolithon (Corallinaceae) generally grow on live or dead coral beds. Amphiroa is also found on the sea grass areas at the edge of lagoons.

Vegetation group of Laurencia obtusa is frequently found on dead coral fragments i.e. at the southeast of Burung Island.

Some species of sea grass (Spermatophyta) like Enhalus acoroides, Thalassia sp., and Halophyla spp. are found distributed in this area especially on the edge of lagoons and sand flats..

\section{TRANSECTS}

A total number of 73 transect lines were observed covering 3,098 square meters. From the transect lines individual and group algae were counted. Table II and III shows the quantities, distribution and dominance of algal groups.

\section{The Area of Tikus Island}

In this area red algae are found more abundant and more varied on rocky substrates than on sandy habitats. The amount of Rhodophyta is smaller than Phaeophyta (Sargassum spp., Padina spp., and Turbinaria spp.) and Chlorophyta (Caulerpa spp. and Halimeda spp.). Some of the species such as Laurencia spp., Acanthophora spp., Hypnea spp., and Gracilaria spp. are found in greater number than Eucheuma spp., Amphiroa spp., and Galaxaura spp.

\section{The Area of Pari Island}

In this area red algae (Rhodophyta) are smaller in number than Phaeophyta. Acanthophora and Hypnea (Rhodophyta); Sargassum and Padina (Phaeophyta); Caulerpa and Halimeda (Chlorophyta) are frequently found on sandy substrates. Besides the algae mentioned above, Laurencia are also found on rocky substrates. At certain areas Eucheuma spinosum is found in a relatively great number.

\section{The Northeast Area of Burung Island}

Phaeophyta in this area dominate over other algae. The important algae are Padina, Sargassum, Laurencia, Acanthophora, Gracilaria, and Hypnea. Caulerpa and Halimeda are the most common algae of the Chlorophyta. 


\section{WANDA SURJANA ATMADJA}

Table II. Distribution of algal numbers obtained from transect

\begin{tabular}{|c|c|c|c|c|c|c|c|}
\hline \multirow{3}{*}{ Locality } & \multirow{3}{*}{ Algae } & \multicolumn{6}{|c|}{ Habitats and quantities } \\
\hline & & \multicolumn{2}{|c|}{ sand } & \multicolumn{2}{|c|}{ rock } & \multicolumn{2}{|c|}{ mud } \\
\hline & & ind. & + & ind. & + & ind. & + \\
\hline \multirow{4}{*}{$\begin{array}{l}\text { 1. Kongsi Isl. } \\
\text { Jul. } 72 \text { - Jun. ' } 73\end{array}$} & Rhodophy ta & 840 & 59 & 547 & 164 & 35 & - \\
\hline & Phaeophyta & 1420 & 67 & 745 & 56 & 28 & - \\
\hline & Chlorophyta & 713 & 77 & 471 & 124 & 33 & - \\
\hline & & 2973 & 202 & 1763 & 344 & 96 & - \\
\hline \multirow{4}{*}{$\begin{array}{l}\text { 2. Pari Isl. } \\
\text { Jul. } 73 \text {-Jan.'74. }\end{array}$} & Rhodophyta & 530 & 25 & 378 & 78 & 2 & - \\
\hline & Phaeophyta & 715 & 22 & 1017 & 87 & - & - \\
\hline & Chlorophyta & 405 & 17 & 409 & 62 & 8 & - \\
\hline & & 1650 & 64 & 1804 & 227 & 10 & - \\
\hline \multirow{4}{*}{$\begin{array}{l}\text { 3. Tikus Isl. } \\
\text { Feb.'75-Jun.'75. }\end{array}$} & Rhodophyta & 72 & 15 & 130 & 29 & - & - \\
\hline & Phaeophyta & 256 & 19 & 274 & 23 & - & - \\
\hline & Chlorophyta & 138 & 10 & 97 & 44 & - & - \\
\hline & & 467 & 44 & 501 & 96 & - & - \\
\hline \multirow{4}{*}{$\begin{array}{l}\text { 4. Burung Isl. } \\
\text { Feb.'74-Jan.'75. }\end{array}$} & Rhodophyta & 100 & 10 & 11 & 9 & 1 & - \\
\hline & Phaeophyta & 328 & 20 & 28 & 9 & - & - \\
\hline & Chlorophvta & 91 & 7 & 11 & 3 & - & - \\
\hline & & 519 & 37 & so & 21 & 1 & $=$ \\
\hline
\end{tabular}

Dominant species in :

1. Acanthophora spp., Eucheuma spinosum. Padina spp. and Sargasswn spp.

2. Acanthophora spp., Laurencia spp., Sargassum spp., Turbinaria spp., Padina spp., Caulerpa spp., and Halimeda spp.

3. and 4. Acanthophora spp., Laurencia spp., Sargassum spp., Padina spp., Caulerpa spp., and Halimeda spp.-

\section{The Area of the Kongsi Island}

Concentration of algae are found predominantly on rocky habitats. Most of the Acanthophora, Eucheuma, Caulerpa, and Halimeda grow on this habitat. Of the Phaeophyta, Padina is found distributed on sandy and rocky habitats. Next important members of Phaeophyta are Sargassum and Turbinaria.

\section{STANDING CROPS}

Measurements of standing crops from 15 stations shows that wet weight percentage of red algae varies from 18 to 100\%. In the area of Eucheuma spinosum populations, the variations are between 18 to $45 \%$. 
NOTES ON THE DISTRIBUTION OF RED ALGAE

Table III. The number distribution and dominancy of benthic marine algae obtained from transect

\begin{tabular}{|c|c|c|c|c|c|c|}
\hline \multirow{3}{*}{$\wedge \lg$ a $e$} & \multicolumn{5}{|c|}{ Habitats and quantities } & \\
\hline & \multicolumn{2}{|c|}{ Sand } & \multicolumn{2}{|c|}{ rock } & \multicolumn{2}{|c|}{ mud } \\
\hline & ind. & + & ind. & + & ind. & + \\
\hline Rhodophyta & 1542 & 109 & 1066 & 280 & 38 & - \\
\hline \multicolumn{7}{|l|}{ Common species } \\
\hline Acanthophora spp.* & 961 & 61 & 389 & 137 & 29 & - \\
\hline Lourencia spp.* & 144 & 17 & 134 & 66 & 4 & - \\
\hline $\begin{array}{l}\text { Hypnea spp. } \\
\text { Gracilaria spp. }\end{array}$ & $\begin{array}{r}140 \\
80\end{array}$ & $\begin{array}{r}13 \\
2\end{array}$ & $\begin{array}{r}38 \\
133\end{array}$ & $\begin{array}{l}21 \\
17\end{array}$ & $\begin{array}{l}2 \\
-\end{array}$ & $\begin{array}{l}- \\
-\end{array}$ \\
\hline Phaeophyta & 2719 & 128 & 2064 & 175 & 28 & - \\
\hline \multicolumn{7}{|l|}{ Common species } \\
\hline Sargassum spp.* & .430 & 30 & 597 & 77 & - & - \\
\hline Padina spp." & 1670 & 69 & 754 & 37 & 27 & - \\
\hline Turbinaria spp. & 304 & 11 & 557 & 32 & - & - \\
\hline Dictyota spp. & 149 & 7 & 158 & 29 & - & - \\
\hline Chlorophyta & 1347 & 110 & 988 & 233 & $4 I$ & - \\
\hline Caulerpa spp.* & 403 & 72 & 448 & 178 & 16 & - \\
\hline Halimeda spp. & 743 & 30 & 369 & 42 & 15 & - \\
\hline Ulva lactuca & 59 & 1 & 58 & 1 & - & - \\
\hline
\end{tabular}

Communities of red algae reaching $100 \%$ are found to consist of Laurencia spp. only. The average red algae standing crops is $49.60 \%$ (Table IV).

\section{EPIPHYTIC ALGAE}

Red algae are also found on rafts used for culture experiment of Eucheuma spinosum in the lagoons and also as epiphytes on many thalli of other algae like Sargassum spp. Those are Acanthophora spicifera, Laurencia, Hypnea, Jania, Ceramium, and Polysiphonia. These algae are generally present on those rafts after one or two months following the beginning of cultivation experiments. 
WANDA SURJANA ATMADJA

Table IV. Wet weight composition per square meter obtained from standing crop measurements

\begin{tabular}{|c|c|c|c|c|c|c|}
\hline \multirow[t]{2}{*}{ Locality } & \multirow[t]{2}{*}{ A I g a e } & \multirow[b]{2}{*}{$31 / 8-74$} & \multicolumn{4}{|c|}{ Time and percentage of wet weight } \\
\hline & & & $1 / 9-74$ & $29 / 9-74$ & $29 / 9-74$ & $27 / 1-75$ \\
\hline \multirow{4}{*}{$\begin{array}{l}\text { Kongsi } \\
\text { Island. }\end{array}$} & Rhodophyta & 43.40 & 26.81 & 36.00 & 63.44 & 91.02 \\
\hline & Phaeophyta & 28.66 & 67.57 & 29.80 & 19.78 & 14.91 \\
\hline & Chlorophyta & 9.86 & 1.15 & 13.44 & 15.31 & 17.79 \\
\hline & Dominant spe & \multicolumn{5}{|c|}{$\begin{array}{l}\text { Acanthophore spp, Eucheuma spinosum, Sargassum spp. and } H \\
\text { limeda spp. }\end{array}$} \\
\hline-- & Rhodophyta & 68.01 & 9.85 & & & \\
\hline \multirow{2}{*}{$\begin{array}{l}\text { Tikus } \\
\text { Island. }\end{array}$} & Phaeophyta & 10.28 & 4.78 & & & \\
\hline & Chlorophyta & 18.44 & 58.37 & & & \\
\hline \multirow{5}{*}{$\begin{array}{l}\text { Burung } \\
\text { Island. }\end{array}$} & \multicolumn{6}{|c|}{ Dominant species: Laurencia spp., Hypnea spp. and Acanthophora spp. } \\
\hline & Rhodophyta & 51.03 & 82.08 & 100.00 & 67.42 & \\
\hline & Phaeophyta & 32.58 & 14.80 & - & 31.28 & \\
\hline & Chlorophyta & 3.22 & 3.00 & - & 1.30 & \\
\hline & \multicolumn{5}{|c|}{ Dominant species : Laurencia spp., Hypnea spp. and Sargassum spp. } & --- \\
\hline & Rhodophyta & 18.72 & 45.36 & 48.18 & 25.13 & \\
\hline & Phaeophyta & 28.67 & 14.13 & 15.83 & 35.95 & \\
\hline & Chlorophyta & 22.20 & 13.06 & 8.23 & 13.66 & \\
\hline & Dominant spe & $\begin{array}{l}\text { Acanthop } \\
\text { sum spp. }\end{array}$ & $\underset{\text { binaria }}{\text { spp., } E}$ & $\begin{array}{l}\text { uma spir } \\
\text { and } \mathrm{Hal}\end{array}$ & $\begin{array}{l}n, \text { Graci } \\
a \text { spp. }\end{array}$ & spp., Sarg \\
\hline
\end{tabular}

5. ENVIRONMENTAL FACTORS

a. Biological factors

Generally some marine animals like Synapta sp. and Bohadschia sp. are found amongst algal vegetations in relatively great numbers. Animals like Lynkia sp.,Lambis-lambis, and Lambis chiragra-chiragra are also found but in smaller numbers. On sandy habitats Archaster typicus, Laganum sp., Deadema sp., Microthele nobilis, Bohadschia sp., H. scabra, Cerithium vertagus, Cypraea sp., Strombus sp., and some species of bivalves such as Venus purpurea are found.

b. Physical factors

Air and water temperatures vary from $26.50^{\circ}-33^{\circ} \mathrm{C}$, salinities 30-32\%, $022.50-4.50 \mathrm{cc} / 1$ and $\mathrm{pH}$ 6-8. 


\section{DISCUSSION}

Thirty five species of red algae have been recorded from this area. This is much richer in species than that recorded by COURTENAY (1974) from Laudardale, Florida (11 species) and by DOTY (1970) from some areas in the Philippines (16 species) and still richer than that recorded by TSUDA \& BELK (1972) from Caroline Island (32 species). But as compared to the 555 species recorded from Indonesian waters by VAN BOSSE (1928), the 320 species from around north Wellington Island ( ADAMS 1972) and 63 species from the waters of the Gulf of Mexico, (STAIDINGER \& BREEDVELD 1971) the record from Pari Island is certainly not yet sufficient. From 54 species of useful algae from Indonesian waters (SUGIARTO 1968), 21 species are red algae and about half are known to this area.

The great species variations found here are possibly due to environmental conditions which are agreeable for red algal growth. The red algae are relatively adapted to shallow regions (FELDMAN 1951). Based on their substrates, the red algae in this area are generally "ephylithes" but are also found as "epiphytes" such as Laurencia, Hypnea, and Acanthophora spicifera. Exposure to direct sunlight on sandy habitats are tolerated by Acanthophora spicifera and $A$. dendroides. Some red algae such as Amphiroa sp. grow on seagrass areas, or attached to living corals such as Halymenia durvilleae and Hypnea sp. Galaxaura spp. generally grow on reef slopes. The red algae of the area can grow perennially and annually.

Visual observations show that the growth of thalli of some species of red algae generally occurs in August, September, and October. Further attention will be paid on this matter in the next study.

\section{CONCLUSIONS}

From the investigation that had been done in the coral reef of Pari Island, the following results are obtained :

1. Thirty five species of red algae have been identified from the collections obtained from the coral reef of Pari Island.

2. The species variations and the percentage of wet weight per square meter of the red algae were greater in comparison to brown and green algae.

3. Generally the algae grows in great numbers as "ephylithes" at moats of the reef than on sandy or muddy habitats.

4. The quantities and qualities of growth are possibly related to environmental factors of this area. 


\section{WANDA SURJANA ATMADJA}

5. Laurencia spp. are found in single populations whereas Eucheuma spinosum is nearly always found in mixed populations.

6 . The growth of algae of the area are apparent as perennial or annual.

\section{ACKNOWLEDGEMENTS}

The author is very grateful to the Director of the National Institute of Oseanology, Dr. APRILANI SUGIARTO and to the Deputy Director, Messrs. SUJATNO BIROWO and KASIJAN ROMIMOHTARTO for their continuous interest in this work and for their advices and help rendered. My thanks are due to all of my colleagues, especially Messrs. SULISTIJO, PRAP-TO DARSONO, and D.P. PRASENO for their cooperations. And also to the staff of the Division of Algae.

\section{REFERENCES}

ADAMS, N.M. 1972. The marine algae of the Wellington area: A list of species. Rec. Dom. Mus 8 (4) : 43 $-98$.

COURTENAY JR, W.R., D.J. HERREMA, M.J. THOMPSOM, W.P. AZZINARD, and J. van MONT-FRANS 1974. Ecological monitoring of beach erosion control projects, Proward Country, Florida and Adjacent areas. U.S. Army, Corps. Eng., Coast Eng. Res. Cent., Tech. Mem. 44 ; 1 - 88.

DAWSON, E.Y. 1955. How to know the seaweeds. W.M.C. Brown Company: 197 pp.

DAWSON, E.Y. 1966. Marine Botany. Holt, Rinehart and Wilson, Inc., : 371 pp.

DOTY, M.S. 1970. The red algal genus Eucheuma in the Philippines. University of Hawaii. Hawaii Botanical Science Paper, No. $18: 1$ - 358.

FELDMAN, J. 1951. Ecology of marine algae. In: Man. Phyc., (G.M. SMITH ed.) Ronald Press Co. New York : $314-334$

STAIDINGER, K.A. and J.A.VAN BREEDVELD 1971.Benthic marine algae from waters adjacent to the Crystal River electric power plant (1969 and 1970). Flor. Dept. Nat. Res., Mar. Res. Lab., St. Petersburg Florida, Prof, paper serie $16: 1$ - 46.

SUGIARTO, A. 1968. Seaweed resources from Indonesias waters. Paper presented in Workshop on Food, Djakarta : 1 - 21.

SUKARNO 1975. Penelitian pendahuluan tentang kepadatan karang batu di terumbu karang Pulau Ayer, Laut Jawa. Paper presented in the Seminar Biologi IV, Yogyakarta, 1975.

SURJODINOTO 1967. Laporan sementara tentang kemungkinan pendirian suatu "Marine Biological Station/Laboratory" di Pulau Seribu (c.q. Pulau Pari). L.P.L.-MIPI (unpublished report).

SURJODINOTO and N. PARDANINGSIH 1964. Preliminary report on the algae of Pulau Seribu (edible and commercial seaweed from southern Pulau Seribu). L.P.L.-M.I.P.I. (un plublished report).

TAYLOR, W.R. 1962. Marine algae of the northeastern coast of North America. Univ. Michigan Press., USA : 509 pp.

TSUDA, R.T. 1972. Some marine algae from Truk and Kuop, Caroline Islands. Atoll Res. Bull. 155 : 1 - 10. 
NOTES ON THE DISTRIBUTION OF RED ALGAE

TSUDA, R.T. and M.S. BELK 1972. Additional records of marine benthic algae from Yap, Western Caroline Islands. Atoll. Res. Bull., 156: 1 - 5 .

VARMA, P.R. and K.K. RAO 1962. Algal resources of Pamban area. Indian Jour. Fish. Min. Food Agr. Gov. India, IX A (1) : 205-211.

ZANEVELD, J.S. 1955. Economic marine algae of tropical south and east Asia and their utilization. Ind o. Pacific Fish. Comm., spec, publ. 3:1 - 55.

VAN BOSSE, A.W. 1928. Rhodophyceae, Gigartinales et Rhodimeniales. Liste des Algues du Siboga. Siboga Exped. LIXd, IV : 1 - 141. 